\title{
A two-year monitoring period of the genetic properties of clade 2.3.2.1c H5N1 viruses in Nigeria reveals the emergence and co-circulation of distinct genotypes
}

\author{
Agnes Laleye $^{\mathrm{a}, \mathrm{b}}$, Tony Joannis ${ }^{\mathrm{b}}$, Ismaila Shittu ${ }^{\mathrm{b}}$, Clement Meseko ${ }^{\mathrm{b}}$, Gianpiero Zamperin ${ }^{\mathrm{c}}$, Adelaide \\ Milani $^{\mathrm{c}}$, Bianca Zecchin ${ }^{\mathrm{c}}$, Alice Fusaro ${ }^{\mathrm{c}}$, Isabella Monne ${ }^{\mathrm{c}}$ and Celia Abolnik ${ }^{\mathrm{a}}$ \\ ${ }^{a}$ Department of Production Animal Studies, Faculty of Veterinary Science, University of Pretoria, Onderstepoort, \\ 0110, South Africa \\ ${ }^{\mathrm{b}}$ National Veterinary Research Institute, Vom, Nigeria \\ ${ }^{\mathrm{c}}$ Istituto Zooproflattico Sperimentale delle Venezie, Legnaro, Italy
}

\section{Highlights}

-We analysed the full genome sequences of one hundred 2.3.2.1c H5N1 viruses isolated from Nigerian poultry.

- Phylogenetic analyses showed evidence of co-circulation of distinct genotypes and the emergence of reassortant viruses.

- One reassortant strain with a genetic marker for antiviral resistance in the NA gene became predominant in 2016.

- Nigerian isolates demonstrated close evolutionary relationships with European and Middle Eastern strains of H5N1.

\begin{abstract}
:
Phylogenetic analyses of the complete genomes of the highly pathogenic avian influenza (HPAI) 2.3.2.1c H5N1 virus strains causing outbreaks in Nigeria's poultry population from 2014 to 2016 showed evidence of distinct co-circulating genotypes and the emergence of reassortant viruses. One of these reassortants became the predominant strain by 2016, and the NA protein of this strain possessed the V96A substitution known to confer reduced susceptibility to neuraminidase inhibiting antiviral drugs. Our findings also demonstrated evolutionary relationships between Nigerian isolates and European and Middle Eastern strains of H5N1 which provides further evidence for the proposed role of migratory birds in spreading the virus, although the involvement of the live poultry trade cannot be excluded. Efforts must be directed towards improving biosecurity and gaining the cooperation of poultry farmers for more effective control of HPAI, in order to mitigate the emergence of HPAI strains in Nigeria with biological properties that are potentially even more dangerous to animals and humans.
\end{abstract}

Keywords: HPAI, full-genome sequencing, co-circulation, reassortment, mutation, evolution 


\section{Introduction}

Avian influenza is caused by influenza A viruses of the Orthomyxoviridae family which are segmented, negative sense, single-stranded RNA viruses (McCauley et al., 2012). The genome consists of eight segments encoding at least eleven functional proteins: polymerase basic 2 (PB2) on segment 1, polymerase basic 1 (PB1) plus mitochondria-associated protein (PB1-F2) on segment 2, polymerase A (PA) plus PA-X fusion protein on segment 3, haemagglutinin (HA) glycoprotein on segment 4, nucleocapsid protein (NP) on segment 5, neuraminidase (NA) glycoprotein on segment 6, matrix protein (M1) plus the ionic channel protein (M2) on segment 7 , and nonstructural protein 1 (NS1) plus nuclear export protein (NEP/NS2) on segment 8 (Cai et al., 2010; Wright et al., 2007). Influenza A viruses are further classified into subtypes based on the antigenic relationship of their surface glycoproteins, HA and NA (Munster \& Fouchier, 2009). To date, $18 \mathrm{HA}$ (H1 to H18) and $11 \mathrm{NA}$ (N1 to N11) subtypes have been identified (Swayne \& Halvorson, 2003; Fouchier, 2005; Watanabe et al., 2014)

The HA protein is responsible for viral attachment, and is produced as a precursor molecule, HA0, which must be cleaved to HA1 and HA2 to expose the fusion protein by host proteases. This proteolytic activation of the HA molecule is a prime determinant of the pathogenicity of avian influenza viruses which express large variation in cleavability (Klenk and Rott, 1988; Vey et al, 1992; Horimoto \& Kawaoka, 1994). The typical cleavage site of LPAI viruses has single basic amino acids and is limited to activation by localized trypsin-like proteases mostly found in the respiratory and intestinal tract of the host. HPAI viruses however possess multiple basic amino acids at the HA0 cleavage site cleavable by more ubiquitous proteases probably subtilisinrelated endoproteases such as furin (Stieneke-Gröber et al., 1992). HPAI viruses are thus able to replicate throughout the host system, damaging multiple vital organs and tissues, resulting in severe clinical manifestations and possibly death. Another important factor influencing HA cleavability is the presence of a carbohydrate side chain (glycosylation) close to the cleavage site which interferes with protease accessibility. Loss of this molecule enhances cleavability and hence pathogenicity (Klenk et al., 2013).

HPAI outbreaks caused by the $\mathrm{H} 5$ or $\mathrm{H} 7$ subtypes have continued to adversely impact the global poultry and associated industries. Great economic losses during outbreaks result from excessive mortalities in affected flocks and culling of in-contact or susceptible birds as part of control measures. In 2006, the first incursion of HPAI H5N1 in Nigeria was reported, sequel to the emergence of the A/Goose/Guangdong/1/1996 H5N1 (GsGD) in Guangdong province of China in 1996 which circulated extensively in Asia and was subsequently disseminated to Europe and Africa (Xu et al., 1999; Joannis et al., 2006; Fusaro et al., 2009; 2010). Control measures, largely based on depopulation and decontamination employed by the Government in partnership with donor agencies, led to the eradication of the virus from the country within two years (Oladokun et al., 2012). Seven years after the last HPAI H5N1 outbreaks in the country, two incidences were reported simultaneously from Kano and Lagos states between late 2014 and early 2015 (OIE, 2015). Phylogenetic analysis of the HA showed that the virus belonged to the 
genetic clade 2.3.2.1c and clustered with H5 viruses collected in China in 2013 and with an H5N1 virus (A/Alberta/01/2014) isolated from a Canadian resident who had recently visited China (Monne et al., 2015). Clade 2.3.2.1c, which was first reported from China in whooper swans (Bi et al,2015) has been isolated from several other wild birds species, along the Central Asian flyway and demonstrated high virulence in mice and ferrets (Bi et al., 2016; Marchenko et al., 2016; Pearce et al, 2017). The virus subsequently spread to other states of Nigeria as well as other West African countries including Burkina Faso, Ghana, Ivory Coast, Niger, Cameroon and Togo; some of which are still reporting outbreaks (OIE, 2017). Two genetic groups within clade 2.3.2.1c, namely WA1 and WA2 were identified in seven of the gene segments (Tassoni et al., 2016). Specifically, the WA1 group was described in Ghana, Burkina Faso, Nigeria and Niger, whereas the WA2 group was restricted to Niger and Ivory Coast. Subsequently, a more recent analysis of the HA gene of 14 Nigerian viruses demonstrated co-circulation of both groups in the country (Shittu et al., 2017). Previous analyses were limited in the number of samples analysed (Tassoni et al., 2016), or by analysis of only the HA (Shittu et al., 2017). Here, we analysed the complete genomes of 100 representative isolates collected between 2015 and 2016 from 16 states and the Federal Capital Territory, to provide a better understanding of the genetic characteristics and evolution of the 2.3.2.1c H5N1 viruses circulating in Nigeria.

\section{Materials and Methods}

\subsection{Sample collection and virus isolation}

Field outbreaks of a disease with case definitions consistent with HPAI were reported in poultry from late December 2014 in Nigeria (Fig 1). Whole carcasses from affected farms and live bird markets were collected by the Avian Influenza Control Project (AICP) surveillance officers and shipped cold to the Regional Lab for Animal Influenzas and other Transboundary Animal Diseases, National Veterinary Research Institute, Vom, for definitive diagnosis. Liver, spleen, lung, trachea and intestine were harvested aseptically, pooled during necropsy and processed for virus isolation according to standard protocol (OIE, 2015). Briefly, 5 grams of pooled tissues were homogenized in a $20 \%(\mathrm{w} / \mathrm{v})$ suspension with antibiotics and isotonic phosphate-buffered saline (PBS), $\mathrm{pH} 7.0-7.4$. After centrifugation at $1000 \mathrm{~g}$ for 5 minutes, $0.2 \mathrm{ml}$ supernatant of the tissue homogenate was inoculated into each allantoic cavity of five 9-11 day-old embryonating chicken eggs (ECE) obtained from a specific antibody negative flock (SAN). 


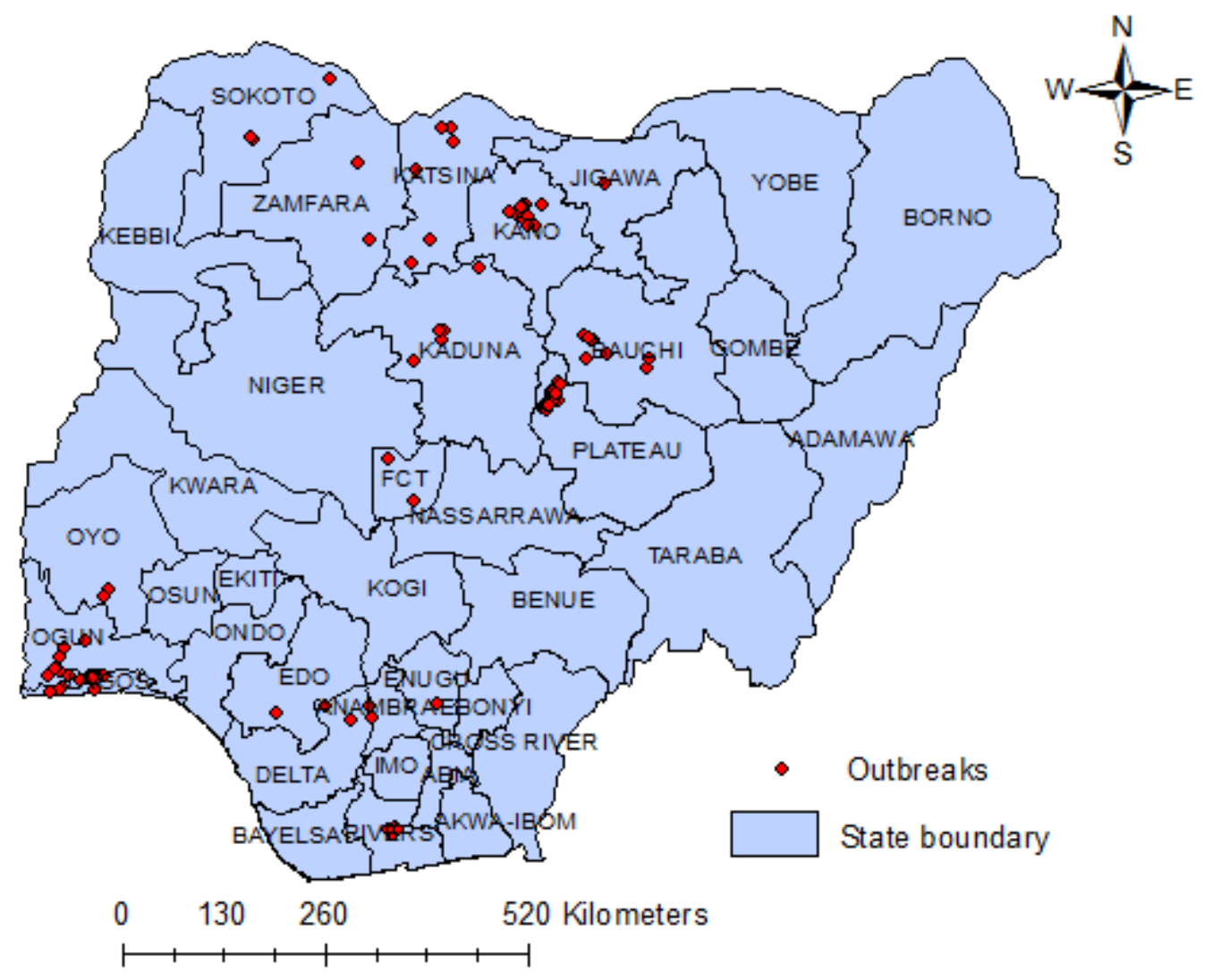

Fig. 1. A map of Nigeria showing all the states as well as the Federal Capital Territory (FCT) with orange diamond shapes indicating the location of the 2015-2016 H5N1 viruses included in this study.

Inoculated eggs were incubated in a humidified chamber at $37^{\circ} \mathrm{C}$ and examined daily for embryo vitality. Eggs containing dead embryos 24 hours post inoculation were chilled at $4^{\circ} \mathrm{C}$. Allantoic fluid (ALF) was harvested and tested for haemagglutination (HA) activity using $10 \%$ chicken red blood cells and all positive ALFs were bio-banked. HA positive ALFs were tested for avian influenza in a one-step RT-PCR assay targeting the matrix (M) gene (Fouchier et al., 2000) using the GeneAmp ${ }^{\circledR}$ Gold RNA PCR core kit in a 9700 thermocycler (Life Technologies, Foster City, CA, USA). M-gene positive samples were further subtyped for H5 (Slomka et al 2007) and N1 (Huang et al., 2013). Amplified PCR products were analysed by gel electrophoresis with $1.5 \%$ agarose stained with ethidium bromide (SIGMA, Germany) and visualized using Gel Documentation system (Biostep, Germany). Samples were only declared negative if the virus failed to amplify in embryonating chicken eggs after two successive passages.

One hundred H5N1 isolates were randomly selected from a pool of HA positive samples (Supplemental Table 1), packaged according to IATA regulations and sent for further genetic characterization to the World Organization for Animal Health Reference Laboratory and the Food and Agriculture Organization of the United Nations Reference Centre for Animal Influenza at the Istituto Zooprofilattico Sperimentale delle Venezie, Italy. 


\subsection{Library preparation, Illumina sequencing, and data analysis}

Viral RNA was extracted from the 100 H5N1-infected ALFs using a Nucleospin RNA II kit (Macherey-Nagel, Duren, Germany). Complete influenza A virus genomes were amplified using the SuperScript III one-step reverse transcription-PCR (RT-PCR) system with PlatinumTaq high fidelity (Invitrogen, Carlsbad, CA) and one pair of primers complementary to the conserved elements of the influenza A virus promoter as described by Zhou et al. (2009). All amplified products were visualized on a $0.7 \%$ agarose gel stained with GelRed. Sequencing libraries were obtained using a Nextera DNA XT sample preparation kit (Illumina) according to manufacturer's instructions and quantified using a Qubit dsDNA high-sensitivity kit (Invitrogen). The average fragment length was determined using an Agilent high-sensitivity bioanalyzer kit. Finally, the indexed libraries were pooled in equimolar concentrations and sequenced in multiplex for 300-bp paired-end Illumina MiSeq analysis according to the manufacturer's instructions.

To obtain consensus sequences, raw sequence reads were inspected using FastQC v0.11.2 to assess the quality of data coming from the high-throughput sequencing pipelines. Raw data were filtered by removing: a) reads with more than $10 \%$ of undetermined ("N") bases; b) reads with more than 100 bases with Q score below 7; c) duplicated paired-end reads. Remaining reads were clipped from Illumina adaptors Nextera XT with scythe v0.991 (https://github.cohe) and trimmed with sickle v1.33 (https://github.com/najoshi/sickle). Reads shorter than 80 bases or unpaired after previous filters were discarded.

High quality reads were aligned against a reference genome using BWA v0.7.12 ( $\mathrm{Li}$ and Durbin, 2010). Alignments were processed with SAMtools v0.1.19 (Li et al., 2009) to convert them in BAM format and sort them by position. Single Nucleotide Polymorphisms (SNPs) were called using LoFreq v2.1.2 (Wilm et al., 2012). According to LoFreq usage recommendations, each alignment was first processed with Picard-tools v2.1.0 (http://picard.sourceforge.net) and GATK v3.5 (McKenna et al., 2010; Van der Auwera et al., 2013) in order to correct potential errors, realign reads around indels and recalibrate base quality. LoFreq was then run on the correct alignments to produce a vcf file from which the consensus sequences were generated. SNPs with a frequency lower than $25 \%$ were filtered out.

Gene sequences were submitted to the GenBank database under accession numbers MF112254MF113041.

\subsection{Phylogenetic and sequence analysis}

A BLAST search for each gene segment of the 100 HPAI H5N1 viruses was performed in the GISAID database and the most closely-related sequences were downloaded (November, 2016), as well as sequences of H5N1 viruses from the 2006-8 Nigerian outbreaks. Alignments were performed using the on-line program Mafft v.7.0 (Katoh, 2013). Maximum likelihood (ML) phylogenetic trees were generated using PhyML v.3.1 (Guindon et al., 2010), incorporating a general time-reversible (GTR) model of nucleotide substitution with a gamma-distribution of 
among-site rate variation (with four rate categories, $\Gamma 4$ ) and a subtree pruning and regrafting (SPR) branch-swapping search procedure. To confirm the tree topologies, additional Neighbourjoining trees were constructed in MEGA6 (Tamura et al., 2013). In both cases, bootstrap resampling process (1,000 replications) was used to assess the robustness of individual nodes on the trees (Darriba et al., 2012). The ML trees were visualized in FigTree v 1.4.2. (http://tree.bio.ed.ac.uk/software/figtree/). The genetic distance within the group of viruses isolated in each of the two years was computed in MEGA6. Amino acid sequences were translated in BioEdit (Hall, 1999), and translated HA gene sequences were scanned for potential N-linked glycosylation sites using the NetNGlyc1.0 Server (http://www.cbs.dtu.dk/services/NetNGlyc/) Tate et al, 2014. The O-glycosylation sites were similarly predicted with the NetOGlyc4.0 algorithm (http://www.cbs.dtu.dk/services/NetOGlyc/) (Steentoft et al., 2015).

\section{Results}

\subsection{The origins of clade 2.3.2.1c in West Africa}

The complete genomes of 100 H5N1 viruses collected from January 2015 to June 2016 in Nigerian poultry were sequenced. The deduced amino acid sequence of the HA cleavage site (HA0) in all viruses was PQRERRRK_R*GLF, typical of HPAI. This HA0 cleavage site motif is one amino acid shorter at position 329 (H5 numbering) compared to clade 2.2 viruses previously reported in Nigeria (Joannis et al., 2006), a variation that has been reported in other viruses of clade 2.3.2.1 (Haque et al., 2014; Marinova-Petkova et al., 2012) and has been shown to increase pathogenicity of the virus in mallard ducks (Tang et al., 2008). The HA sequences of all Nigerian viruses from 2015-2016 fall within clade 2.3.2.1c and cluster with H5N1 viruses identified since 2014 in Asia, the Middle East, Eastern Europe and other West African countries including Niger, Ghana, Burkina Faso and Ivory Coast (Fig 2). Specific amino acid signatures were considered in defining sub-groups observed within this clade. The Nigerian viruses collected in 2015 are dispersed throughout the HA tree, indicating the plausible occurrence of multiple independent introductions or the evolution of the virus into multiple genetic groups, locally after the introduction of the WA1 and WA2 into the country. In particular, 46 viruses (23 isolated in 2015 coloured in red in Fig. 2 and all isolated in 2016, coloured in green) belong to a previously described sub group, WA2 (Tassoni et al., 2016). The sub-clade containing these 46 viruses had a bootstrap value of $62 \%$ and clustered with viruses from Niger, Ivory Coast, Bulgarian and Romanian wild birds (similarities range from $98 \%$ to $99 \%$ ). All the viruses of this group shared the amino acid signature D154N and they further acquired the mutation R145G during their evolution. Interestingly, all 23 viruses collected in 2016 in Nigeria (apart from isolate 5840-77) formed a separate group within the WA2 cluster, supported by a high bootstrap value (98\%) and were characterized by an additional amino acid signature (I200V). This group also included a virus collected in Niger in 2016 and two Nigerian viruses from 2015. 

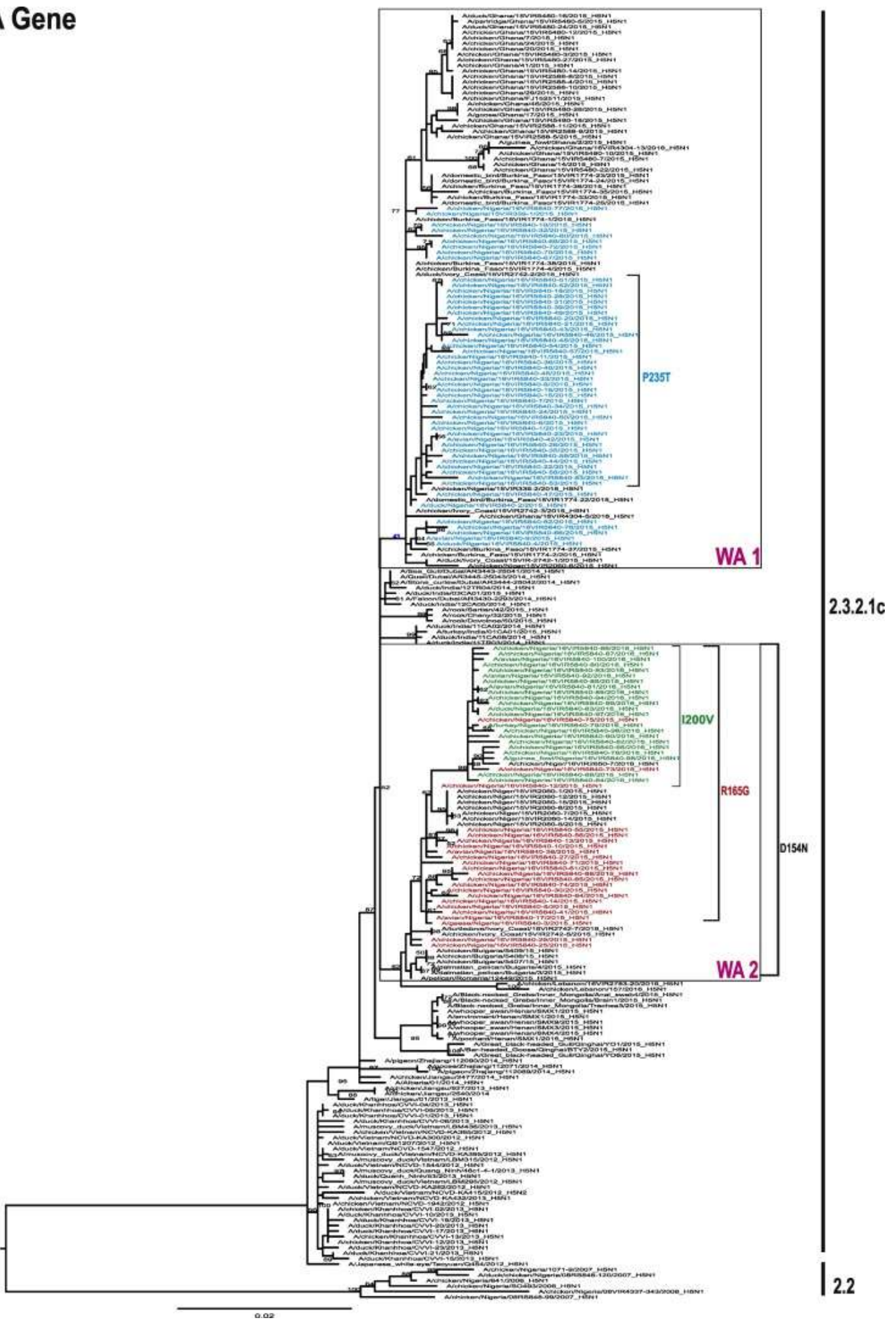

Fig. 2. Maximum-likelihood phylogenetic tree of the HA gene segment of highly pathogenic avian influenza (H5N1) viruses from Nigeria and related viruses obtained from public database. All the 2016 viruses (except 584077) cluster within the green group with good bootstrap value, $98 \%$. This group also clusters with some 2015 viruses (red) viruses, which appear to be the progenitor. While the remaining 2015 viruses (blue) cluster separately. Only bootstrap values $>50 \%$ are indicated on the tree. 


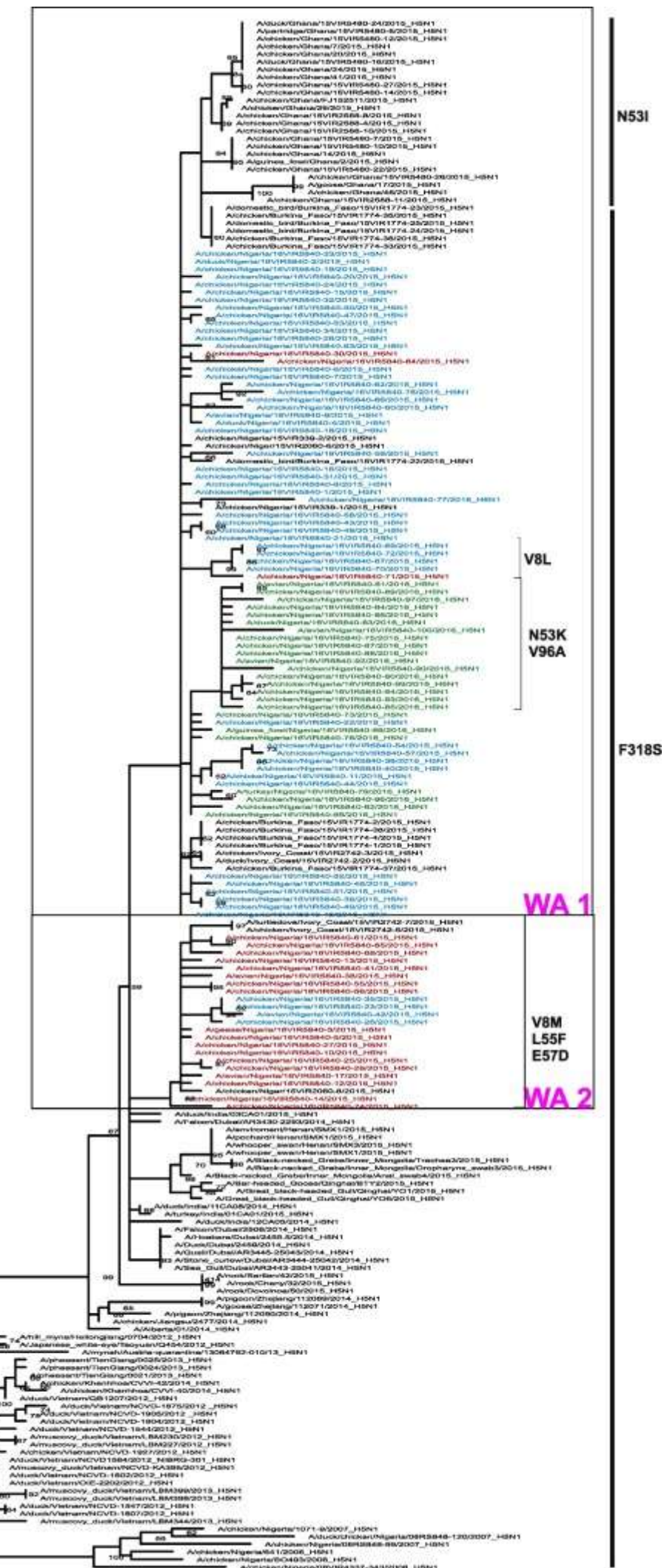

Fig. 3. Maximum-likelihood phylogenetic tree of the NA gene segment of highly pathogenic avian influenza (H5N1) viruses from Nigeria and related viruses obtained from public database. 
The remaining 2015 Nigerian viruses $(n=54$, coloured blue in Fig 2) cluster separately with H5N1 from Burkina Faso, Ghana and Niger within the group designated as WA1 by Tassoni $e t$ al. (2016). With a bootstrap value of only $43 \%$, this group is not well supported in the HA gene phylogeny, probably due to the low phylogenetic signal in the Nigerian sequence data. Indeed, no amino acid signature characteristic of the group was identified in the HA gene. Other mutations observed were limited to some of the viruses but not common to the entire group (data not shown)

Similar to the HA gene, topologies of the phylogenetic trees obtained from the remaining seven gene segments indicate that the Nigerian viruses cluster with viruses of 2.3.2.1c clade collected in African, Middle Eastern and Asian countries since 2014 (Fig 3, Supplemental figs 1 to 6). Characteristic amino acid signatures were observed in all the proteins, especially for the 2016 Nigerian viruses (data not shown). Both WA1 and WA2 groups were observed in the phylogenetic trees obtained for the NA and internal genes except the NS1/ NS2 gene, but only supported by high bootstrap values in the PA/PA-X (97\%) and PB2 (63\%) genes.

\subsection{Intra-clade reassortment}

Analyses of the HA, NA and each of the internal gene segments show that the 2016 Nigerian viruses cluster together, supported by high bootstrap values (>87\%) and long branches in the segments encoding the PB2, PB1, PA/PA-X, M1/M2 and NS1/NS2 genes, but not the NP gene. In the HA and NS phylogenies, the 2016 viruses clustered with a group of 2015 Nigerian viruses (in red in Fig. 2 and Supplemental Fig 3), the presumed ancestors, and with viruses collected in 2015-16 in Niger. In the remaining genes however, the 2016 viruses cluster with different 2015 viruses (coloured in blue in Fig. 3, Supplemental figs 1, 2, 4, 5, 6) providing evidence of reassortment between the two groups, which gave rise to this strain circulating in 2016. Other reassortment events are apparent by the presence of both WA1 and WA2 subgroups in the phylogenies inferred for the different gene segments, except the NS1/NS2 gene. (Table 1). The WA1 sub-clade was responsible for the initial outbreaks reported from Lagos and Kano states during late 2014 and early 2015 respectively, whilst subsequent outbreaks that occurred in these two states within two weeks, fall within the WA2 group. Based on the gene constellations, we observed nine reassortant viruses, most of which had limited circulation (Table 1). However, one reassortant strain first detected in Katsina State with an HA belonging to the WA1 group but NA and internal genes of the WA2 group, apparently became the predominant strain by 2016 and across the different states of the Federation. This strain was also identified among 2016 viruses from Niger in the public database. 
Table 1: Genome constellations of the reassortant H5N1 viruses isolated in 2015-2016 in Nigeria

\begin{tabular}{cccccccccc}
\hline & Nos & HA & M & NA & NP & NS & PA & PBI & PB2 \\
\hline A & 42 & WA1 & WA1 & WA1 & WA1 & & WA1 & WA1 & WA1 \\
B & 17 & WA2 & WA2 & WA2 & WA2 & & WA2 & WA2 & WA2 \\
$\mathrm{R}_{0}$ & 3 & WA1 & WA1 & WA1 & WA1 & & WA1 & WA2 & WA1 \\
$\mathrm{R}_{1}$ & 5 & WA1 & WA2 & WA1 & WA1 & & WA1 & WA1 & WA1 \\
$\mathrm{R}_{2}$ & 1 & WA1 & WA1 & WA1 & WA2 & WA1 & WA1 & WA1 \\
$\mathrm{R}_{3}$ & 25 & WA2 & WA1 & WA1 & WA1 & & WA1 & WA1 & WA1 \\
$\mathrm{R}_{4}$ & 1 & WA1 & WA2 & WA1 & WA2 & & WA1 & WA1 & WA2 \\
$\mathrm{R}_{5}$ & 1 & WA2 & WA2 & WA1 & WA2 & & WA2 & WA2 & WA2 \\
$\mathrm{R}_{6}$ & 3 & WA1 & WA2 & WA1 & WA1 & WA1 & WA1 & WA1 \\
$\mathrm{R}_{7}$ & 1 & WA2 & WA1 & WA1 & WA1 & WA2 & WA1 & WA2 \\
$\mathrm{R}_{8}$ & 1 & WA2 & WA2 & WA1 & WA1 & & WA2 & WA2 & WA1 \\
\hline
\end{tabular}

Column one represents the different gene constellations observed in the virus isolates, A and B having all genes of WA1 and WA2 respectively while R* have combination of genes from both groups. NS gene had a poor resolution to determine the different groups.

\subsection{Genetic and antigenic drift in clade 2.3.2.1c}

None of the mutations known to be related to resistance to neuraminidase inhibitors, such as R152K, R292K, E119V, D198N, H274Y, N294S (Ferraris and Bruno, 2008), were observed in any of the 2015 Nigerian viruses, but all viruses isolated from Nigerian poultry in 2016 possessed an alanine substitution from valine at position 96 in the NA protein. The V96A substitution is known to confer reduced susceptibility to zanamivir and oseltamivir (Hurt et al., 2007; Boltz et al., 2010; Ilyushina et al., 2010). Of note are a group of 2015 Nigerian viruses, together with viruses from Niger and Ivory Coast, that share some common amino acid signatures in both the NA (V8M, L55F and E57D) and NP (I217T, N319K) proteins. The N319K mutation has been associated with enhanced replication efficiency in mammalian cells (Gabriel et al., 2008).

Specific amino acid signatures were also observed across the internal genes. Of note are those in the NS protein that suggest a correlation between the molecular markers and geographical location including S59R, G72E, L124I, which are confined to viruses from Nigeria only. D134N, E224K and Y242H mutations in the NS protein were limited to viruses isolated in 2016. The polymerase also contained mutations that are confined to Nigeria only, namely M195T in PB1 and D161E, R175K, E195K/G, R299K in PB2 (data not shown).

The predicted $\mathrm{N}$-glycosylation sites identified in the HA of all the H5N1 viruses analysed (11Asn-Ser-Thr13, 23Asn-ValThr25, 165Asn-Asn-Thr167, 286Asn-Ser-Ser288, 484AsnGly- 
Thr486 and 543Asn-Gly-Ser545) were conserved across all isolates. Two predicted Oglycosylation sites at positions 144 and 336 in the HA were conserved in only a few of $(n=10)$ the viruses, isolated in both 2015 and 2016. O-glycosylation in the HA protein is also thought to affect receptor-binding (Rauff et al, 2016)

\section{Discussion}

Since 2003, HPAI H5N1viral infections have increased in severity in terms of reported outbreaks in poultry as well as the economic impact in affected countries/regions and the virus has expanded its host range from several avian species to mammalian species including humans. Thus it has been regarded as the most threatening influenza A subtype, and should HPAI H5N1 viruses acquire adaptations for sustained human-to-human transmission, a human pandemic could still ensue (Webster et al., 2006).Globally, there have been 859 human cases of H5N1 with 453 deaths as at July 2017 (WHO, 2017). Thus far, only one human fatality has been reported in Nigeria following infection with a clade 2.2 H5N1 virus (Breiman et al., 2007; Monne et al., 2008).

In the current study, phylogenetic analysis of the HA gene showed a clustering of 2015-2016 H5N1 Clade 2.3.2.1c Nigerian viruses with strains from Eastern Europe (Bulgaria, Romania), the Middle East (United Arab Emirates and Lebanon) and Asia (India). An earlier study established an epidemiological link between Nigerian and Asian H5N1 strains (Monne et al., 2015) but it was unclear whether human activities such as importation of poultry/poultry products or migratory birds were responsible for introducing the virus to Nigeria. The number of sequences analysed in the previous study was limited $(n=2)$ compared to 100 sequences employed in the present study, here we demonstrate clearer evolutionary relationships between Nigerian isolates and European and Middle Eastern strains of H5N1 which were recently released in public databases.

The role of migratory birds in the transmission of HPAI H5N1 has often been debated since 2005, when bar-headed geese and other species were infected with HPAI around the Qinghai Lake and subsequent spread to European, Middle Eastern and African countries (Webster et al., 2006). Migratory birds from Eastern Europe or Russia seem to have played an important role in the introduction of the 2.2 clade in Nigeria, responsible of the 2006-2008 epidemic (Fusaro et al., 2009), where the genomes of H5NI clade 2.2 viruses detected in Gombe State within the expansive Hadejia Nguru wetland axis in Nigeria was $99.3 \%$ in the HA; $99.8 \%$ in the NA and $100 \%$ in the M1/M2 genes identical to those of a virus isolated from a migratory bird- Cygnus olor from Czech Republic in Eastern Europe. During the 2006-2008 epidemics, the country experienced increased number of outbreaks in the December to January cold period, which coincided with winter migration of waterfowl from Europe to sub Saharan West Africa (Munster and Fouchier, 2009). Shortly after the current virus was detected in Nigeria, a closely related strain of H5N1 clade 2.3.2.1c was also detected in wild birds, including a hunting falcon in Dubai in the Middle East (Naguib et al., 2015) and the authors described an intercontinental 
spread and a relationship with the strain found in Nigeria. This study suggests that migratory birds might have played a role in the introduction of HPAI H5N1 clade 2.3.2.1c to West Africa, as an epidemiological linkage of HPAI introduction from Eastern Europe through migratory waterfowls has been reinforced by our findings. In addition, the spatio-temporal distribution of the H5N1 clade 2.3.2.1c along major migratory birds' flyway connecting Europe/Middle East and Africa suggests the possibility of such scenario (Bi et al., 2016). Whereas this work does not primarily consider the more recent HPAI H5N8 outbreaks in Africa the outbreaks of HPAI H5N8 virus have aligned near-perfectly with the known international fly pathways of wild migratory birds (OIE, 2017). This, however, cannot exclude the role of poultry/poultry products trade between Nigeria and these countries. Further study, especially within the migratory birds, may be required to ascertain their role in the introduction of the virus.

Previous report of the index H5N1 clade 2.3.2.1c virus in Nigeria showed a high degree of identity with Chinese H5N1 viruses from 2013. The HA gene sequence was shown to cluster with H5 viruses collected in China in 2013 and with an H5N1 virus (A/Alberta/01/2014) isolated from a Canadian resident who had returned from China (similarity 99.3\%-99.5\%) (Pabbaraju et $a l ., 2013)$. Just as for the virus from Canada, 7 of 8 gene segments of the virus from Nigeria clustered with HPAI A (H5N1) virus circulating in Vietnam and China, while the PB2 gene segment resulted from reassortment with viruses circulating in the same Asian countries but belonged to the H9N2 subtype (Monne et al., 2015).

Mutations such as the D94N, S133A, S155N that increases binding to $\alpha-2,6$, sialic acid receptor of the HA which potentiate mammalian host adaptation (Wang et al., 2010; Pearce et al., 2017), were not observed in this study suggesting that the Nigerian viruses still maintain preference for avian hosts as suggested by Shittu and colleagues, 2017. However, co-circulation of the observed genotypes led to the emergence of a predominant strain which possessed a mutation in the NA protein (V96A) known to confer reduced susceptibility to neuraminidase inhibitors. We also observe some characteristic amino acid signatures in the NS and polymerase proteins of the Nigerian viruses, suggesting a correlation between molecular markers and geographical location. These demonstrate how continuous virus replication in susceptible hosts in endemic regions potentially drives virus evolution. Although, the implication of some of the mutations observed in this study are yet to be reported, experimental investigations may yet reveal a significant role they play, either in isolation or together, in virulence or host preference of the virus.

The reassortment events observed are not unexpected given the intensity and magnitude of outbreaks and continuous detection and isolation of the virus in the field from 2015 through 2016 within the poultry population. At the time of this report, the HPAI H5N1 epidemic was still ongoing in Nigeria. In addition, the HPAI H5N8 clade 2.3.4.4 has been reported in the country (OIE, 2017). Hence, the possible occurrence of reassortment events between these co-circulating viruses should be closely monitored, since new strains with unpredictable virulence may arise. These may have the potential to infect new susceptible hosts across species, especially when contact 
spread is not effectively prevented. Reassortant virus may acquire gain of functions through continued circulation in susceptible hosts, which could enhance its ability to infect new susceptible hosts with potential to drive evolution in an unknown direction (Dennehy, 2017). The identification of the predominant reassortant strain in Niger suggests that it also spread outside Nigeria possibly through poultry /poultry product movements within the West African region (Ekong et al., 2017).

The incremental changes and host adaptations of the phylogenetically distinguishable groups WA1 and WA2 co-circulating in the country as observed in this study and in an earlier report by Shittu et al., (2017) raises concerns around poor biosecurity, especially in backyard poultry and live bird markets compounded by uninhibited movement of poultry and poultry products across a wide expanse of ecological zones. This study shows that one of the reassortant strains between the two subgroups became predominant by 2016 . We did not find any correlation between genetic divergence and geographic distance among the Nigerian H5N1 viruses for any of the eight gene segments (data not shown). This finding indicates that the different genetic variants have been dispersed throughout the country, probably through the commercial movement of poultry.

The short evolutionary span of less than a year, within which co-circulating strains of influenza virus have reassorted and emerged as independent lineages in Nigerian poultry, have both ecological and economic implications. Evidently, it is a consequence of protracted circulation due to shortcomings in control measure policy. Control efforts must therefore address lapses in biosecurity and ensure the cooperation of owners of birds for more effective control of HPAI, and so-doing reduce the risk of emergent strains with biological properties that are potentially even more dangerous to animals and humans.

\section{Acknowledgements}

This work was supported by the Food and Agriculture Organization of the United Nations (UN-FAO) with funding from the United States Agency for International Development (USAID) under the OSRO/GLO/501/USA project entitled "Emergency Assistance for prevention and control of H5N1 HPAI in West and Central Africa". We thank Drs Gwenaelle Dauphin, Lidewij Wiersma and Beatrice Mouille of the UN-FAO and team for their technical support. The content of this article is the responsibility of the author(s) and does not necessarily reflect the views of UN-FAO, USAID or the United States Government.We acknowledge the support of the management of National Veterinary Research Institute, Vom and the technical assistance of the NVRI transboundary animal diseases lab and the OIE/FAO reference centre for animal influenza at the Istituto Zooprofilattico Sperimentale delle Venezie. Special thanks to Dr. Ronke Odita for designing the map. We also acknowledge the authors, the originating and submitting laboratories of the sequences from the Global Initiative on Sharing All Influenza Data EpiFlu Database on which this research is based in part. 


\section{References}

Bi, Y., Chen, J., Zhang, Z. et al (2016). Highly pathogenic avian influenza H5N1 Clade 2.3.2.1c virus in migratory birds, 2014-2015 Virol. Sin. 31: 300. https://doi.org/10.1007/s12250-016-3750-4

Bi, Y. Zhang Z, Liu W et al (2015). Highly Pathogenic Avian Influenza A (H5N1) Virus Struck Migratory Birds in China in 2015. Sci. Rep. 5, 12986; doi: 10.1038/srep12986

Boltz DA1, Douangngeun B, Phommachanh P, Sinthasak S, Mondry R, Obert C, Seiler P, Keating R, Suzuki Y, Hiramatsu H, Govorkova EA, Webster RG Emergence of H5N1 avian influenza viruses with reduced sensitivity to neuraminidase inhibitors and novel reassortants in Lao People's Democratic Republic. J Gen Virol. 2010 Apr; 91 (Pt 4):949-59. doi: 10.1099/vir.0.017459-0.

Breiman, R.F., Nasidi, A., Katz, M.A., Njenga, M.K. and Vertefeuille, J., 2007. Preparedness for highly pathogenic avian influenza pandemic in Africa. Emerg Infect Dis, 13(10), p.1453

Cai, Z, Zhang, T \& Wan, X, 2010, "A Computational Framework for Influenza Antigenic Cartography", PLos Computational Biology, vol. 6, no. 10, pp. e1000949

Darriba D, Taboada GL, Doallo R, Posada D, 2012. jModelTest 2: more models, new heuristics and parallel computing Nature Methods 9, 772. doi:10.1038/nmeth.2109

Dennehy JJ, 2017. Evolutionary ecology of virus emergence. Ann. N.Y. Acad. Sci. 1389: 124-146 @2016 New York Academy of Sciences. Issue: The Year in Evolutionary Biology

Ekong PS, Fountain-Jones NM, Alkhamis MA. (2017). Spatiotemporal evolutionary epidemiology of H5N1 highly pathogenic avian influenza in West Africa and Nigeria, 2006-2015. Transbound Emerg Dis.; 00:1-13.

https://doi.org/10.1111/tbed.12680

Fouchier RA, Bestebroer TM, Herfst S et al (2000) Detection of influenza A viruses from different species by PCR amplification of conserved sequences in the matrix gene. J Clin Microbiol 38:4096-4101

Fouchier, RAM, Munster, V, Wallensten, A, Bestebroer, TM, Herfst, S, Smith, D, Rimmelzwaan, GF, Olsen, B \& Osterhaus, ADME, 2005, "Characterization of a novel influenza A virus hemagglutinin subtype (H16) obtained from black-headed gulls", Journal of Virology, vol. 79, no. 5, pp. 2814-2822

Fusaro A, Joannis T, Monne I et al (2009) Introduction into Nigeria of a distinct genotype of avian influenza virus (H5N1).Emerg Infect Dis 15:445-447. doi:10.3201/eid1503.081161

Gabriel G1, Herwig A, Klenk HD. Interaction of polymerase subunit PB2 and NP with importin alpha1 is a determinant of host range of influenza A virus. PLoS Pathog. 2008 Feb 8;4 (2):e11. doi:

10.1371/journal.ppat.0040011

Guindon S., Dufayard J.F., Lefort V., Anisimova M., Hordijk W., Gascuel O "New Algorithms and Methods to Estimate Maximum-Likelihood Phylogenies: Assessing the Performance of PhyML 3.0." Systematic Biology, 59(3):307-21, 2010

Hall TA (1999) Symposium on RNA biology. III. RNA, tool and target. Research Triangle Park, North Carolina, USA. October 15-17, 1999. Proceedings Nucleic Acids Symp Ser 41:1-218 (citeulike-article-id: 691774) 
Haque ME, Giasuddin M, Chowdhury EH, Islam MR (2014) Molecular evolution of H5N1 highly pathogenic avian influenza viruses in Bangladesh between 2007 and 2012. Avian Pathol 43:183-194.

doi:10.1080/03079457.2014.898244

Huang Y, Khan M, Ma ndoiu II (2013) Neuraminidase subtyping of avian influenza viruses with PrimerHunterdesigned primers and quadruplicate primer pools. PLoS One 8:e81842. doi:10.1371/journal.pone.0081842

Hurt AC1, Selleck P, Komadina N, Shaw R, Brown L, Barr IG. Susceptibility of highly pathogenic A(H5N1) avian influenza viruses to the neuraminidase inhibitors and adamantanes. Antiviral Res. 2007 Mar;73(3):228-31. doi: 10.1016/j.antiviral.2006.10.004

Ilyushina NA1, Seiler JP, Rehg JE, Webster RG, Govorkova EA.Effect of neuraminidase inhibitor-resistant mutations on pathogenicity of clade $2.2 \mathrm{~A} /$ Turkey/15/06 (H5N1) influenza virus in ferrets. PLoS Pathog. 2010 May 27;6(5):e1000933. doi: 10.1371/journal.ppat.1000933

Joannis T, Lombin LH, De Benedictis P et al (2006) Confirmation of H5N1 avian influenza in Africa. Vet Rec 158:309-310. doi:10. 1136/vr.158.9.309-b

Katoh, Standley 2013. MAFFT multiple sequence alignment software version 7: improvements in performance and usability. (Outlines version 7) Molecular Biology and Evolution 30:772-780 http://mafft.cbrc.jp/alignment/software/

Klenk, HD \& Rott, R, 1988, "The molecular biology of influenza virus pathogenicity", Advances in Virus Research, vol. 34, pp. 247-81.

Klenk, HD, Garten, W, Matrosovich, M, 2013, "Pathogenesis" in Textbook of Influenza, ed. Webster, R.G., Monto, A.S., Braciale, T.J., Lamb, R.A., 2nd edn, Willey Blackwell, pp. 157-171.

Li H. and Durbin R. (2010) Fast and accurate long-read alignment with Burrows-Wheeler Transform.

Bioinformatics, Epub. [PMID: 20080505]

Li H., Handsaker B., Wysoker A., Fennell T., Ruan J., Homer N., Marth G., Abecasis G., Durbin R. and 1000 Genome Project Data Processing Subgroup (2009) The Sequence alignment/map (SAM) format and SAMtools. Bioinformatics, 25, 2078-9. [PMID: 19505943]

Marinova-Petkova A, Georgiev G, Seiler P et al (2012) Spread of influenza virus A (H5N1) clade 2.3.2.1 to Bulgaria in common buzzards. Emerg Infect Dis 18:1596-1602. doi:10.3201/eid1810. 120357

Marchenko, V.Y., Susloparov, I.M., Kolosova, N.P. et al (2016) Highly pathogenic influenza H5N1 virus of clade 2.3.2.1c in Western Siberia Arch Virol 161: 1645. https://doi.org/10.1007/s00705-016-2800-4

McCauley, JW, Hongo, S, Kaverin, NV, Kochs, G, Lamb, RA, Matrosovich, MN, Perez, DR, Palese, P, Presti, RM, Rimstad, E, Smith, GJD, 2012, "Orthomyxoviridae" in Virus Taxonomy: Classification and Nomenclature of Viruses: 9th Report of the International Committee on Taxonomy of Viruses, eds. King, AMQ, Adams, MJ, Carstens, EB, Lefkowitz, EJ, Elsevier, pp. 749-761.

McKenna A, Hanna M, Banks E, Sivachenko A, Cibulskis K, Kernytsky A, Garimella K, Altshuler D, Gabriel S, Daly M, DePristo MA, 2010. The Genome Analysis Toolkit: a MapReduce framework for analyzing nextgeneration DNA sequencing data. Genome Research 20:1297-303

Monne I, Meseko C, Joannis T, Shittu I, Ahmed M, Tassoni L, et al. Highly pathogenic avian influenza A (H5N1) virus in poultry, Nigeria, 2015. Emerg Infect Dis. 2015; 21:1275-7. http://dx.doi.org/10.3201/eid2107.150421 
Monne, I., Joannis, T.M., Fusaro, A., De Benedictis, P., Lombin, L.H., Ularamu, H., Egbuji, A., Solomon, P., Obi, T.U., Cattoli, G. and Capua, I., 2008. Reassortant avian influenza virus (H5N1) in poultry, Nigeria, 2007. . Emerg Infect Dis, 14(4), p.637.

Munster V.J., Fouchier R.A.M. 2009 Avian influenza virus: Of virus and bird ecology. Vaccines 27, 45: 6340-6344

Naguib MM, Kinne J, Chen H, Chan KH, Joseph S, Wong PC, et al. Outbreaks of highly pathogenic avian influenza H5N1 clade 2.3.2.1c in hunting falcons and kept wild birds in Dubai implicate intercontinental virus spread. J Gen Virol. 2015; 96:3212-22. http://dx.doi.org/10.1099/jgv.0.000274

OIE (2015) Avian influenza. Manual of Diagnostic Tests and Vaccines for Terrestrial Animals. http://www.oie.int/fileadmin/Home/eng/Health_standards/tahm/2.03.04_AI.pdf. Accessed 20 Jul 2015

OIE 2017. OIE Situation Report for avian influenza (latest update: 7 August 2017) http://www.oie.int/animal-healthin-the-world/update-on-avian-influenza/2017/

Oladokun AT, Meseko CA, Ighodalo E et al (2012) Effect of intervention on the control of highly pathogenic avian influenza in Nigeria. Pan Afr Med J 13:14. doi:10.11604/pamj.2012.13.14. 1106

Pabbaraju K, Tellier R, Wong S, Li Y, Bastien N, Tang JW, et al. Full-genome analysis of avian influenza A(H5N1) virus from a human, North America, 2013. Emerg Infect Dis. 2014; 20:887-91.

http://dx.doi.org/10.3201/eid2005.140164

Pearce MB, Pappas C, Gustin KM et al (2017). Enhanced virulence of clade 2.3.2.1 highly pathogenic avian influenza AH5N1 viruses in ferrets. Virology 502 114-122 https://doi.org/10.1016/j.virol.2016.12.024

Rauff D, Strydom C, Abolnik C. Evolutionary consequences of a decade of vaccination against subtype H6N2 influenza. Virology. 2016 Nov; 498:226-39

Shittu, I., Meseko, C.A., Gado, D.A. et al. Highly pathogenic avian influenza (H5N1) in Nigeria in 2015: evidence of widespread circulation of WA2 clade 2.3.2.1c Arch Virol (2017) 162 (3): 841 - 847. doi:10.1007/s00705-016$3149-4$

Slomka MJ, Coward VJ, Banks J et al (2007) Identification of sensitive and specific avian influenza polymerase chain reaction methods through blind ring trials organized in the European Union. Avian Dis 51:227-234.

doi:10.1637/7674-063006R1.1

Steentoft, C., Vakhrushev, S.Y., Joshi, H.J., Kong, Y., Vester-Christensen, M.B., Schjoldager, K.,T., Lavrsen, K., Dabelsteen, S., Pedersen, N.B., Marcos-Silva, L., Gupta, R., Bennett, E.P., Mandel, U., Brunak, S., Wandall, H.H., Levery, S.B., Clausen, H., 2015. Precision mapping of the human O-GalNAc glycoproteome through SimpleCell technology. ЕМВО J. 32 (10), 1478-1488 〈http://www.cbs.dtu.dk/services/NetOGlyc/〉

Stieneke-Gröber, A, Vey, M, Angliker, H, Shaw, E, Thomas, G, Roberts, C, Klenk, HD \& Garten, W, 1992, "Influenza virus hemagglutinin with multibasic cleavage site is activated by furin, a subtilisin-like endoprotease.", The EMBO Journal, vol. 11, no. 7, pp. 2407-2414

Swayne, D.E. \& Halvorson, D.A. 2003, "Influenza" in Diseases of Poultry, eds. Y.M. Saif, H.J. Barnes, J.R. Glisson, A.M. Fadly, L.R. McDouglad \& D.E. Swayne, 11th edn, Iowa State Press, Ames, Iowa, USA, pp. 135-160.

Tamura K, Stecher G, Peterson D, Filipski A, and Kumar S (2013) MEGA6: Molecular Evolutionary Genetics Analysis Version 6.0. Molecular Biology and Evolution 30: 2725-2729 
Tang Y-H, Wu P-P, Sun Q et al (2008) Role of amino acid residues at positions 322 and 329 of hemagglutinin in virulence of H5N1 avian influenza virus. Bing Du Хие Bao 24:340-344

Tassoni L, Fusaro A, Milani A et al (2016) Genetically different highly pathogenic avian influenza A(H5N1) viruses in West Africa, 2015. Emerg Infect Dis. doi:10.3201/eid2212.160578

Tate, M.D., Job, E.R., Deng, Y.M., Gunalan, V., Maurer-Stroh, S., Reading, P.C., 2014. Playing hide and seek: how glycosylation of the influenza virus hemagglutinin can modulate the immune response to infection. Viruses 6 (3), 1294-1316.

Van der Auwera GA, Carneiro M, Hartl C, Poplin R, del Angel G, Levy-Moonshine A, Jordan T, Shakir K, Roazen D, Thibault J, Banks E, Garimella K, Altshuler D, Gabriel S, DePristo M, 2013. From FastQ Data to HighConfidence Variant Calls: The Genome Analysis Toolkit Best Practices Pipeline Current Protocols in Bioinformatics 43:11.10.1-11.10.33

Wang W1, Lu B, Zhou H, Suguitan AL Jr, Cheng X, Subbarao K, Kemble G, Jin H. Glycosylation at 158N of the hemagglutinin protein and receptor binding specificity synergistically affect the antigenicity and immunogenicity of a live attenuated H5N1 A/Vietnam/1203/2004 vaccine virus in ferrets. J Virol. 2010 Jul; 84 (13):6570-7. doi: 10.1128/JVI.00221-10.

Watanabe, T., Zhong, G., Russell, C., Nakajima, N., Hatta, M., Hanson, A., McBride, R., Burke, D., Takahashi, K., Fukuyama, S., Tomita, Y., Maher, E., Watanabe, S., Imai, M., Neumann, G., Hasegawa, H., Paulson, J., Smith, D. \& Kawaoka, Y. 2014, "Circulating Avian Influenza Viruses Closely Related to the 1918 Virus Have Pandemic Potential", Cell Host \& Microbe, vol. 15, no. 6, pp. 692-705

Webster, R. G., Hakawi, A. M., Chen, H., \& Guan, Y. (2006). H5N1 Outbreaks and Enzootic Influenza. Emerg Infect Dis 12(1), 3-8. https://dx.doi.org/10.3201/eid1201.051024

Wilm et al. LoFreq: A sequence-quality aware, ultra-sensitive variant caller for uncovering cell-population heterogeneity from high-throughput sequencing datasets. Nucleic Acids Res. 2012; 40(22):11189-201.

World Health Organization (2017) Cumulative number of confirmed human cases for avian influenza A (H5N1) reported to WHO, 2003-2017.

http://www.who.int/influenza/human_animal_interface/2017_07_25 tableH5N1.pdf?ua=1

World Health Organization. Cumulative number of confirmed human cases of avian influenza A (H5N1) reported to WHO as of March $14^{\text {th }}, 2017$, http://www.who.int/influenza/human_animal_interface/H5N1_cumulative_table_archives/en/

Wright, P. F., G. Neumann, Y. Kawaoka, D. M. Knipe, and P. M.Howley, eds. Fields virology: orthomyxoviruses, 5th ed., vol. 1. Lippincott, Williams \& Wilkins, Philadelphia, PA. pp. 1693-1740. 2007.

Xu, X., Subbarao, Cox, N. J. \& Guo, Y. Genetic characterization of the pathogenic influenza A/Goose/Guangdong/1/96 (H5N1) virus: similarity of its hemagglutinin gene to those of H5N1 viruses from the 1997 outbreaks in Hong Kong. Virology 261, 15-19 (1999)

Zhou B, Donnelly ME, Scholes DT, St. George K, Hatta M, Kawaoka Y, Wentworth DE. 2009. Single-Reaction Genomic Amplification Accelerates Sequencing and Vaccine Production for Classical and Swine Origin Human Influenza A Viruses. J Virol 83:10309-10313 


\section{Supplementary Data}

Supplemental Table 1: Strain name, collection date, and location of highly pathogenic avian influenza H5N1 viruses sequenced from Nigerian poultry during 2015-2016

\begin{tabular}{|c|c|c|c|}
\hline S/No & Virus & Collection date & Location \\
\hline 1. & A/chicken/Nigeria/16VIR-5840-1/2015 & 2015 Jan 14 & Ringi, Kano state \\
\hline 2. & A/duck/Nigeria/16VIR-5840-2/2015 & 2015 Jan 14 & Ifo, Ogun State \\
\hline 3. & A/geese/Nigeria/16VIR-5840-3/2015 & 2015 Jan 13 & Victoria Garden City, Lagos State \\
\hline 4. & A/duck/Nigeria/16VIR-5840-4/2015 & 2015 Jan 13 & Onipanu, Lagos State \\
\hline 5. & A/chicken/Nigeria/16VIR-5840-5/2015 & 2015 Jan 17 & Kano state \\
\hline 6. & A/chicken/Nigeria/16VIR-5840-6/2015 & 2015 Jan 19 & Gwarzo Road, Kano state \\
\hline 7. & - A/chicken/Nigeria/16VIR-5840-7/2015 & 2015 Jan 20 & Tarauni LGA, Kano state \\
\hline 8. & A/chicken/Nigeria/16VIR-5840-8/2015 & 2015 Jan 21 & Lengel Village, Kano state \\
\hline 9. & - A/avian/Nigeria/16VIR-5840-9/2015 & 2015 Jan 24 & Ikorodu, Lagos State \\
\hline $1 C$ & C A/chicken/Nigeria/16VIR-5840-10/2015 & 2015 Jan 25 & Jajira, Kano state \\
\hline 11 & 1 A/chicken/Nigeria/16VIR-5840-11/2015 & 2015 Jan 26 & State Low-cost, Plateau State \\
\hline 12 & $2 \mathrm{~A} /$ chicken/Nigeria/16VIR-5840-12/2015 & 2015 Jan 27 & Chiranchi, Kano state \\
\hline 13 & A/chicken/Nigeria/16VIR-5840-13/2015 & 2015 Jan 27 & Kududdufawa, Kano state \\
\hline 14 & 4 A/chicken/Nigeria/16VIR-5840-14/2015 & 2015 Jan 28 & Port Harcourt, Rivers State \\
\hline 15 & A/chicken/Nigeria/16VIR-5840-15/2015 & 2015 Jan 29 & Wasinmi, Ogun State \\
\hline 16 & A A/chicken/Nigeria/16VIR-5840-16/2015 & 2015 Jan 29 & Janguza, Kano state \\
\hline 17 & I A/avian/Nigeria/16VIR-5840-17/2015 & 2015 Jan 30 & Oshimili North, Delta State \\
\hline $1 \varepsilon$ & A/chicken/Nigeria/16VIR-5840-18/2015 & 2015 Jan 31 & Apata street, Plateau State \\
\hline $1 \mathrm{C}$ & A A/chicken/Nigeria/16VIR-5840-19/2015 & 2015 Feb 2 & Sabonbirni, Sokoto State \\
\hline $2 C$ & C A/chicken/Nigeria/16VIR-5840-20/2015 & 2015 Feb 4 & Narabi, Bauchi State \\
\hline 21 & 1 A/chicken/Nigeria/16VIR-5840-21/2015 & 2015 Feb 5 & Narabi, Bauchi State \\
\hline 22 & $2 \mathrm{~A} /$ chicken/Nigeria/16VIR-5840-22/2015 & 2015 Feb 6 & Ungwan Rimi, Kaduna State \\
\hline 23 & A/chicken/Nigeria/16VIR-5840-23/2015 & 2015 Feb 8 & Ogba, Lagos State \\
\hline 24 & 4 A/chicken/Nigeria/16VIR-5840-24/2015 & 2015 Feb 8 & Kumbotso, Kano state \\
\hline 25 & ( A/chicken/Nigeria/16VIR-5840-25/2015 & 2015 Feb 10 & Inkil, Bauchi State \\
\hline 26 & A/chicken/Nigeria/16VIR-5840-26/2015 & 2015 Feb 11 & Igbesa, Ogun State \\
\hline 27 & 7 A/chicken/Nigeria/16VIR-5840-27/2015 & 2015 Feb 11 & Zamfara State \\
\hline $2 \varepsilon$ & A/chicken/Nigeria/16VIR-5840-28/2015 & 2015 Feb 13 & Bauchi Road, Plateau State \\
\hline $2 \mathrm{c}$ & A/chicken/Nigeria/16VIR-5840-29/2015 & 2015 Feb 13 & Airport, Bauchi State \\
\hline $3 C$ & C A/chicken/Nigeria/16VIR-5840-30/2015 & 2015 Feb 16 & Abukur, Katsina State \\
\hline 31 & 1 A/chicken/Nigeria/16VIR-5840-31/2015 & 2015 Feb 16 & Apata, Plateau State \\
\hline 32 & $2 \mathrm{~A} /$ chicken/Nigeria/16VIR-5840-32/2015 & 2015 Feb 17 & Dange/Shuni, Sokoto State \\
\hline 32 & A/chicken/Nigeria/16VIR-5840-33/2015 & 2015Feb 18 & Bakori, Katsina State \\
\hline 34 & 4 A/chicken/Nigeria/16VIR-5840-34/2015 & 2015 Feb 18 & Rangaza, Kano state \\
\hline 35 & A/chicken/Nigeria/16VIR-5840-35/2015 & 2015 Feb 22 & Igbesa road, Ogun State \\
\hline 36 & A/chicken/Nigeria/16VIR-5840-36/2015 & 2015 Feb 23 & Rantya, Plateau State \\
\hline 37 & $7 \mathrm{~A} /$ chicken/Nigeria/16VIR-5840-37/2015 & 2015 Feb 23 & Gusau, Zamfara State \\
\hline
\end{tabular}


38 A/avian/Nigeria/16VIR-5840-38/2015

3c A/chicken/Nigeria/16VIR-5840-39/2015

4C A/chicken/Nigeria/16VIR-5840-40/2015

41 A/chicken/Nigeria/16VIR-5840-41/2015

42 A/avian/Nigeria/16VIR-5840-42/2015

4? A/chicken/Nigeria/16VIR-5840-43/2015

44 A/chicken/Nigeria/16VIR-5840-44/2015

$45 \mathrm{~A} /$ chicken/Nigeria/16VIR-5840-45/2015

46 A/chicken/Nigeria/16VIR-5840-46/2015

$47 \mathrm{~A} /$ chicken/Nigeria/16VIR-5840-47/2015

$4 \varepsilon$ A/chicken/Nigeria/16VIR-5840-48/2015

4C A/chicken/Nigeria/16VIR-5840-49/2015

5C A/chicken/Nigeria/16VIR-5840-50/2015

$51 \mathrm{~A} /$ chicken/Nigeria/16VIR-5840-51/2015

$52 \mathrm{~A} /$ chicken/Nigeria/16VIR-5840-52/2015

$52 \mathrm{~A} /$ chicken/Nigeria/16VIR-5840-53/2015

54 A/chicken/Nigeria/16VIR-5840-54/2015

$55 \mathrm{~A} /$ chicken/Nigeria/16VIR-5840-55/2015

56 A/chicken/Nigeria/16VIR-5840-56/2015

$57 \mathrm{~A} /$ chicken/Nigeria/16VIR-5840-57/2015

$5 \varepsilon \quad \mathrm{A} /$ chicken/Nigeria/16VIR-5840-58/2015

5C A/chicken/Nigeria/16VIR-5840-59/2015

6C A/chicken/Nigeria/16VIR-5840-60/2015

$61 \mathrm{~A} /$ chicken/Nigeria/16VIR-5840-61/2015

$62 \mathrm{~A} /$ chicken/Nigeria/16VIR-5840-62/2015

$62 \mathrm{~A} /$ chicken/Nigeria/16VIR-5840-63/2015

64 A/chicken/Nigeria/16VIR-5840-64/2015

$65 \mathrm{~A} /$ chicken/Nigeria/16VIR-5840-65/2015

66 A/chicken/Nigeria/16VIR-5840-66/2015

67 A/chicken/Nigeria/16VIR-5840-67/2015

$68 \mathrm{~A} /$ chicken/Nigeria/16VIR-5840-68/2015

6C $\mathrm{A} /$ chicken/Nigeria/16VIR-5840-69/2015

7C A/chicken/Nigeria/16VIR-5840-70/2015

$71 \mathrm{~A} /$ chicken/Nigeria/16VIR-5840-71/2015

$72 \mathrm{~A} /$ chicken/Nigeria/16VIR-5840-72/2015

$73 \mathrm{~A} /$ chicken/Nigeria/16VIR-5840-73/2015

74 A/chicken/Nigeria/16VIR-5840-74/2015

$75 \mathrm{~A} /$ chicken/Nigeria/16VIR-5840-75/2015

$76 \mathrm{~A} /$ chicken/Nigeria/16VIR-5840-76/2015

77 A/chicken/Nigeria/16VIR-5840-77/2016

$7 \varepsilon$ A/chicken/Nigeria/16VIR-5840-78/2016

\begin{tabular}{|c|c|}
\hline 2015 Feb 23 & Gadama, Kano state \\
\hline 2015 Feb 27 & Zaria Road, Plateau State \\
\hline 2015 Feb 27 & Sabo, Kaduna State \\
\hline 2015 Mar 9 & Kumbotso, Kano state \\
\hline 2015 Mar 13 & Ado-Odo/Ota, Ogun State \\
\hline 2015 Mar 18 & Toro, Bauchi State \\
\hline 2015 Mar 21 & Makarfi, Kaduna State \\
\hline 2015 Mar 23 & Jimpi, Bauchi State \\
\hline 2015 Mar 23 & Jos North, Plateau State \\
\hline 2015 Mar 23 & Dausayi, Kano state \\
\hline 2015 Mar 25 & Jimpi, Bauchi State \\
\hline 2015 Mar 25 & Zaria Road, Plateau State \\
\hline 2015 Mar 24 & Durawa, Kano state \\
\hline 2015 Mar 24 & Kofar Dawanau, Kano state \\
\hline 2015 Mar 27 & Federal Low-cost, Plateau State \\
\hline 2015 Mar 30 & Badde, Katsina State \\
\hline 2015 Mar 30 & Rantya Gyel, Plateau State \\
\hline 2015 Apr 2 & Dandishe, Kano state \\
\hline 2015 Apr 14 & Jaba, Kano state \\
\hline 2015 Apr 23 & Federal Low-cost, Plateau State \\
\hline 2015 Apr 24 & Sabuwar Gandu, Katsina State \\
\hline 2015 Apr 28 & Kakuri, Kaduna State \\
\hline 2015 Jul 14 & Ibeshe, Lagos State \\
\hline 2015 Jul 29 & Erinkorodo, Lagos State \\
\hline 2015 Aug 5 & Agbede village, Oyo State \\
\hline 2015 Aug 10 & Aiyedoto, Lagos State \\
\hline 2015 Aug 17 & Agbor, Delta State \\
\hline 2015 Aug 20 & Poromope, Lagos State \\
\hline 2015 Aug 21 & Apapa, Oyo State \\
\hline 2015 Aug 22 & Rumuosi, Rivers State \\
\hline 2015 Aug 24 & Erinkorodo, Lagos State \\
\hline 2015 Sep 17 & Eligbolo, Rivers State \\
\hline 2015 Sep 30 & Elekahia, Rivers State \\
\hline 2015 Oct 7 & Majia, Jigawa State \\
\hline 2015 Oct 27 & Mowe, Ogun State \\
\hline 2015 Nov 13 & Bayelsa State \\
\hline 2015 Dec 11 & Ayedoto, Lagos State \\
\hline 2015 Dec 31 & Kano state \\
\hline 2015 Dec 28 & Okpanam Road, Delta State \\
\hline 2016 Jan 5 & Ozalla junction, Enugu State \\
\hline 2016 Jan 5 & Tudun Yola, Kano state \\
\hline
\end{tabular}


7c A/turkey/Nigeria/16VIR-5840-79/2016

8C A/chicken/Nigeria/16VIR-5840-80/2016

81 A/avian/Nigeria/16VIR-5840-81/2016

82 A/chicken/Nigeria/16VIR-5840-82/2016

8? A/duck/Nigeria/16VIR-5840-83/2016

$84 \mathrm{~A} /$ chicken/Nigeria/16VIR-5840-84/2016

85 A/chicken/Nigeria/16VIR-5840-85/2016

86 A/chicken/Nigeria/16VIR-5840-86/2016

87 A/chicken/Nigeria/16VIR-5840-87/2016

$8 \&$ A/chicken/Nigeria/16VIR-5840-88/2016

8c A/chicken/Nigeria/16VIR-5840-89/2016

9C A/chicken/Nigeria/16VIR-5840-90/2016

91 A/avian/Nigeria/16VIR-5840-91/2016

92 A/avian/Nigeria/16VIR-5840-92/2016

92 A/chicken/Nigeria/16VIR-5840-93/2016

94 A/chicken/Nigeria/16VIR-5840-94/2016

$95 \mathrm{~A} /$ chicken/Nigeria/16VIR-5840-95/2016

96 A/chicken/Nigeria/16VIR-5840-96/2016

$97 \mathrm{~A} /$ chicken/Nigeria/16VIR-5840-97/2016

$9 \varepsilon$ A/guinea fowl/Nigeria/16VIR-5840-98/2016

9c $\mathrm{A} /$ chicken/Nigeria/16VIR-5840-99/2016

1C A/avian/Nigeria/16VIR-5840-100/2016

\begin{tabular}{|c|c|}
\hline 2016 Jan 6 & Gwagwalada Federal Capital Territory (Abuja) \\
\hline 2016 Jan 9 & Rantya, Plateau State \\
\hline 2016 Jan 12 & Sabo Narabi, Bauchi State \\
\hline 2016 Jan 14 & Ogwashu-Uku, Delta State \\
\hline 2016 Jan 11 & Gwale Kano state \\
\hline 2016 Jan 17 & Albasawa Area, Katsina State \\
\hline 2016 Jan 18 & Rukuba Road, Plateau State \\
\hline 2016 Jan 19 & Kabala Costain, Kaduna State \\
\hline 2016 Feb 1 & Kuje, Federal Capital Territory (Abuja) \\
\hline 2016 Feb 1 & Danbare, Kano state \\
\hline 2016 Feb 5 & Tudun Wada, Plateau State \\
\hline 2016 Feb 12 & Burnin Magaji Road, Zamfara State \\
\hline 2016 Feb 16 & Batagarawa Katsina State \\
\hline 2016 Mar 4 & Kurtufamani Road, Katsina State \\
\hline 2016 Mar 7 & Rantya, Plateau State \\
\hline 2016 Mar 7 & Sabon Barki, Plateau State \\
\hline 2016 Mar 7 & Yankatsari, Kano state \\
\hline 2016 Mar10 & Kwannawa Area, Sokoto State \\
\hline 2016 Mar 16 & Ikpoba-Okha, Edo state \\
\hline 2016 Mar 19 & Kera Village, Kano state \\
\hline 2016 Apr 2 & Jos, Plateau State \\
\hline 2016 June 24 & Magbon-Olorunda, Lagos State \\
\hline
\end{tabular}


Supplemental Figure 1: Maximum-likelihood phylogenetic tree of the $\mathrm{M}$ gene segment of highly pathogenic avian influenza $(\mathrm{H} 5 \mathrm{~N} 1)$ viruses from Nigeria and related viruses obtained from public database

\section{Gene}

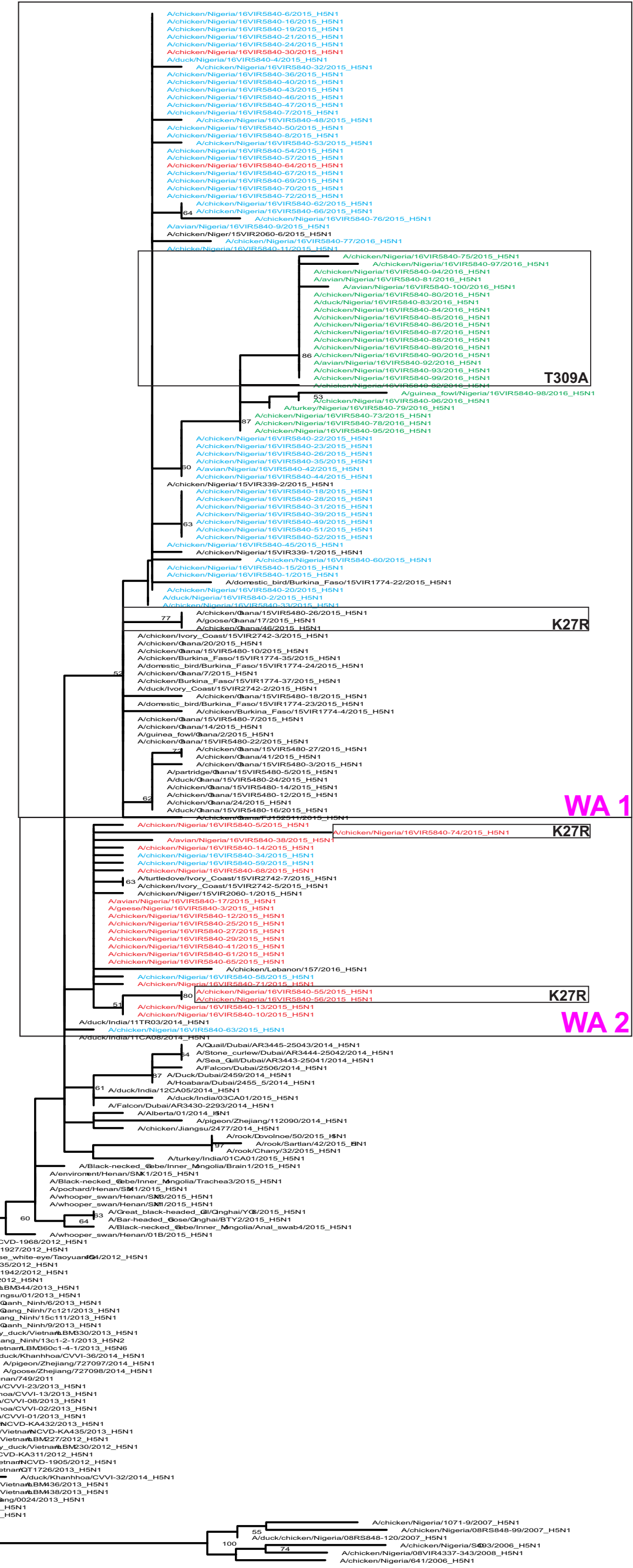


Supplemental Figure 2: Maximum-likelihood phylogenetic tree of the NP gene segment of highly pathogenic avian influenza (H5N1) viruses from Nigeria and related viruses obtained from public database

\section{NP Gene}

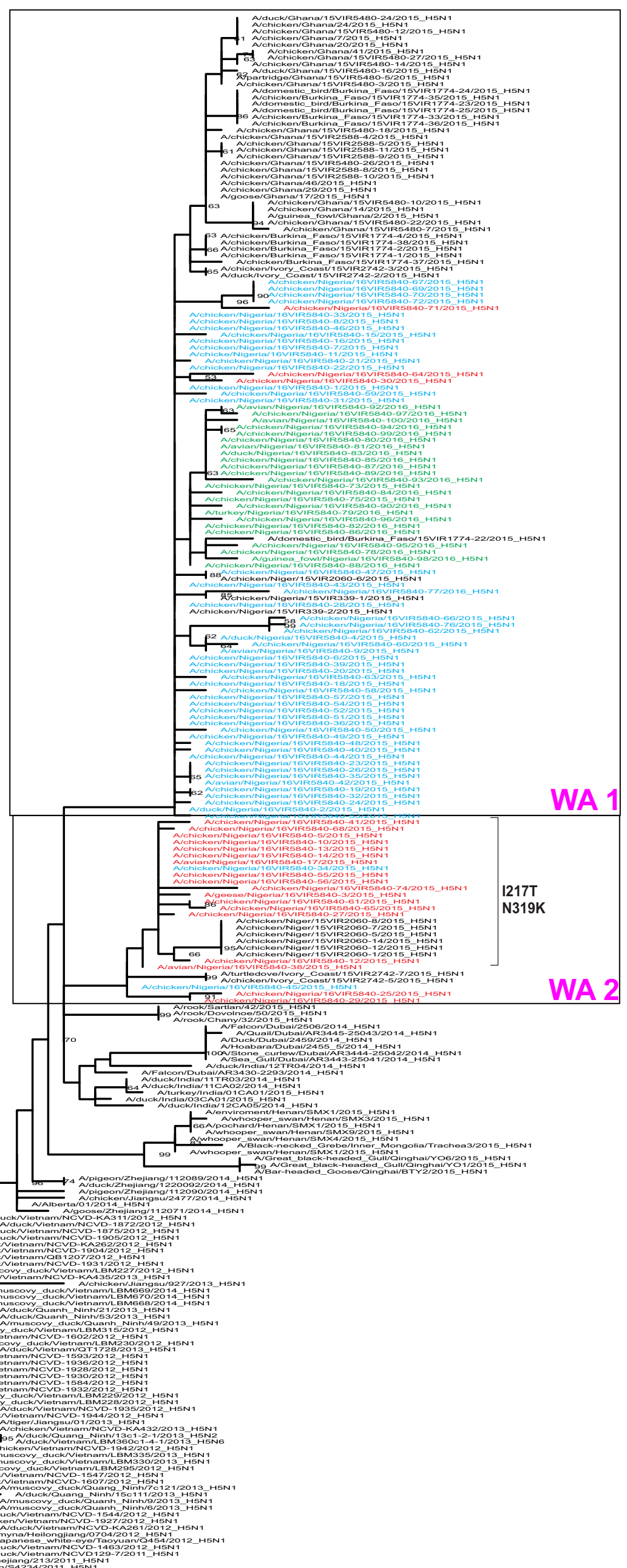

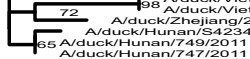


Supplemental Figure 3: Maximum-likelihood phylogenetic tree of the NS gene segment of highly pathogenic avian influenza (H5N1) viruses from Nigeria and related viruses obtained from public database

NS Gene

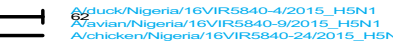


Supplemental Figure 5: Maximum-likelihood phylogenetic tree of the PB1 gene segment of highly pathogenic avian influenza (H5N1) viruses from Nigeria and related viruses obtained from public database

\section{Pb1 Gene}


Supplemental Figure 6: Maximum-likelihood phylogenetic tree of the PB2 gene segment of highly pathogenic avian influenza (H5N1) viruses from Nigeria and related viruses obtained from public database

\section{Pb2 Gene}

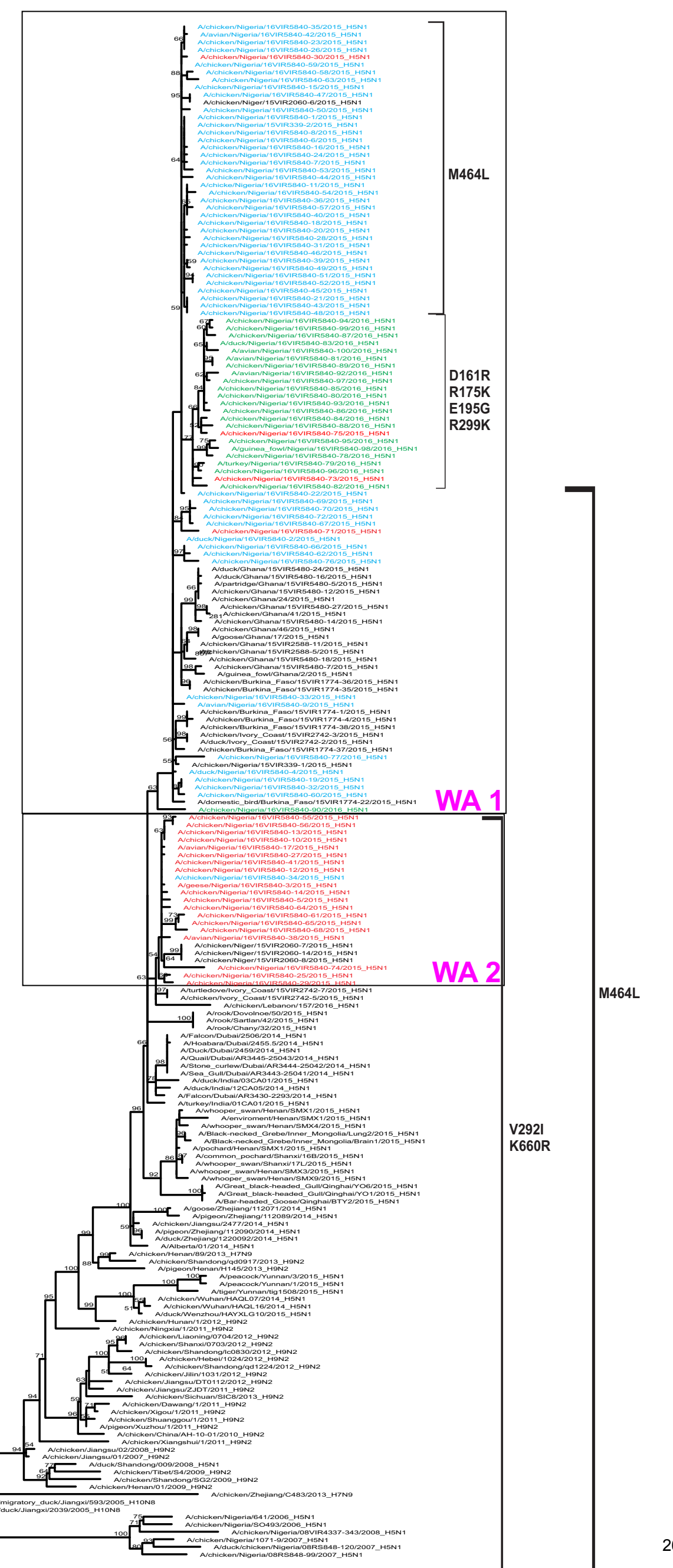

